\title{
Sumienie i nauki o sumieniu z perspektywy neuronauk
}

\section{(Neuroscientific perspectives on conscience and conscience-related research)}

\author{
JÓZEF BREMER \\ Uniwersytet Jagielloński, WSFP „Ignatianum” \\ zjbremer@cyf-kr.edu.pl
}

Streszczenie. W ostatnich latach obserwujemy wzrost empirycznych badań nad biologicznymi korelatami sumienia i podejmowania decyzji moralnych. Centralne pytania zadawane w tych neuronaukowych badaniach dotyczą: a) roli emocji w decyzjach sumienia, b) określenia regionów mózgu skorelowanych z tymi decyzjami. Odpowiadając na nie, omówię najpierw podstawową terminologię oraz przedstawię neuroetyczne analizy P. Churchland, a także wyniki badań empirycznych, przeprowadzonych przez J. Greene'a, A. Damasio i innych. Następnie poddam krytycznej ocenie tezę Greene’a, odmawiającą deontologii statusu teorii moralnej oraz odpowiem na pytanie, czy na podstawie badań empirycznych możemy wnioskować o słuszności jakiejś teorii moralnej (deontologicznej bądź konsekwencjonalistycznej).

Stowa klucze: sumienie; sądy moralne; neuroobrazowanie; neuronauki; emocje; deontologia; konsekwencjonalizm.

\begin{abstract}
Recent years have witnessed a growth in empirical research into the biological correlates of conscience and moral decision-making. The central questions posed and addressed in such neuroscientific investigations concern (a) the role of the emotions in decisions of conscience, and (b) the determining of the particular brain regions that correlate with these decisions. Responding to these, I shall first outline the basic terminology involved and present the neuroethical analyses of Churchland, together
\end{abstract}


with the findings of the empirical studies carried out by Greene, Damasio and others. I then offer a critical assessment of Greene's thesis claiming that deontology should be denied the status of a moral theory, before addressing the issue of whether it is at all possible to arrive at conclusions about the correctness of any sort of moral theory - be it deontological or consequentialist - on the basis of empirical research.

Keywords: conscience; moral judgements; neuroimaging; neurosciences; emotions; deontology; consequentialism.

\section{Wstęp}

We współczesnej psychologii moralności oraz w kognitywistyce przeprowadzono wiele empirycznych badań, mających na celu znalezienie neuronalnych źródeł oraz struktur odpowiedzialnych za dokonywanie potocznych ocen moralnych. Niemniej jednak mówienie o sumieniu jest obarczone swoistą ambiwalencją. Z jednej strony zdaje się ono nie odgrywać żadnej istotnej roli we współczesnych dyskusjach filozoficznych i naukowych, a z drugiej słychać głosy domagające się uszanowania wyborów własnego sumienia, dokonanych przez taką czy inną osobę ${ }^{1}$. W niniejszym artykule skupię się na dwóch zagadnieniach:

a) pierwsze będzie dotyczyć rozumienia, głównie w deontologii, neurobiologicznych i psychologicznych procesów leżących u podstaw wydawania sądów moralnych, a konkretnie u podstaw osądów sumienia. W tym celu przedstawię wyniki interdyscyplinarnych badań eksperymentalnych skupiających się w dużej mierze na pytaniu o rolę emocji w decyzjach sumienia, a równolegle na pytaniu o to, co badania regionów mózgu skorelowanych z emocjami wnoszą do objaśnienia osądów sumienia. Używam terminu „korelacja”, ponieważ neuronauki koncentrują się jedynie na poszukiwaniu neuronalnych korelatów zjawisk psychicznych i nie potrafią badać ani określić jednoznacznych neurologicznych przyczyn sumienia. Najpierw omówię podstawowe terminy, następnie przedstawię neuroetyczne analizy

1 Por. chociażby szeroko ostatnio w naszym kraju dyskutowana kwestia prof. dra hab. med. B. Chazana, który powołując się na konflikt sumienia, odmówił wykonania aborcji u kobiety w 25 . tygodniu ciąży. 
P. Churchland oraz wyniki badań empirycznych, przeprowadzonych przez J. Greene’a, A. Damasio i innych;

b) drugie natomiast będzie odnosić się do krytycznej analizy argumentacji Greene’a, który wyciąga dość szczególną filozoficzną tezę z badań empirycznych, a mianowicie odmawia on słuszności deontologii jako teorii moralnej.

Na podstawie wyników uzyskanych w a) oraz b) postaram się wyciągnąć wnioski dotyczące: i) roli sumienia w podejmowaniu decyzji moralnych, ii) kwestii, czy na podstawie badań empirycznych możemy wnioskować o słuszności jakiejś teorii moralnej (deontologicznej bądź konsekwencjonalistycznej).

\section{Objaśnienia terminologiczne}

Sumienie - (gr. syneīdēsis, łac. conscientia). Łacińska conscientia oznacza zasadniczo „współwiedzę”2, syneīdēsis natomiast „współwidzenie”. Współwiedza i współwidzenie dotyczą zagadnień i zachowań związanych z praktycznym podejściem do czynienia dobra i wyrządzania zła. Stąd pojęcie sumienia jest najczęściej rozważane w etyce i teologii moralnej, w których odnosi się do zdolności ludzkiej psychiki odpowiedzialnej za doświadczanie intuicyjnego (prostego) przekonania powiązanego z reakcją emocjonalną na dobro lub zło moralne danego działania (zamierzonego lub dokonanego).

W języku polskimi do XIX wieku utrzymywały się nazwy: „sąmnienie”, „sumnienie”3, oznaczające „s-umienie” („um” - umysł; „wiedza” - „umienie”). Znaczyły one właściwie „wątpienie”, „podejrzewanie”. Składały się z przedrostka „są” („spólność”) oraz „-imnieć”, czyli „mniemać tak czy inaczej”.

2 "'When two, or more, men know of one and the same fact, they are said to be conscious of it one to another; which is as mach as to know it together.' Hobbes then uses this to explicate the moral meaning of conscience", J. Dewey, "The Terms 'Conscious' and 'Consciousness'”, Journal of Philosophy, Psychology and Scientific Method 3 (1906), 39-41 [s. 39]. Dewey odnosi się tutaj do Lewiatana T. Hobbesa, r. VII.

3 Por. hasło „Sumienie,” w: S. Urbańczyk (red.), Słownik staropolski (Wrocław: Ossolineum, 1977-1981), t. 8, 505-506. 
W języku angielskim terminy „sumienie” (conscience) i „świadomość” (consciousness) są czasami mylone $\mathrm{z}$ dwóch powodów: są one sobie brzmieniowo bliskie oraz obydwa zawierają w sobie wyraz science („wiedza”, „poznanie") ${ }^{4}$. W tym etymologicznym sensie sumienie może być rozumiane jako wiedza o tym, co dobre i złe, $\mathrm{z}$ akcentem na dobre, działa ono analogicznie do alarmu, który się włącza, gdy postępujemy źle. Świadomość oznacza bycie przytomnym, przebudzonym, zdolnym do postrzegania i nabywania wiedzy. Dalej możemy przyjąć, że sumienie (conscience) jest rzeczownikiem oznaczającym jakość charakteru i postępowania danej osoby, zachowywanie zasad moralnych, branie pod uwagę przestrzeganie sprawiedliwości.

Odróżniając sumienie od świadomości, należy także wskazać na to, że pierwszy termin jest zazwyczaj jakościowej natury (osoby mogą mieć różne stopnie moralnej władzy). Chociaż potocznie mówimy o ludziach sumiennych, to mówimy także o ludziach „bez sumienia” czy „pozbawionych sumienia”, „pozbawionych uczuć” (np. psychopaci czy socjopaci). Dzięki neuroobrazowaniu i innym technikom pomiarowym wiemy dzisiaj dużo na temat neurobiologicznych podstaw moralności występujących u tego typu osób ${ }^{5}$.

Natomiast świadomość jest bardziej terminem przeciwstawnym (tertium non datur) w takim sensie, że albo jest się świadomym, albo się nie

4 Zamieszanie w użyciu terminów conscience i conscious wynika stąd, że ten ostatni jest czasem używany jako rzeczownik synonimiczny z consciousness. Por. M. Wayne, Conscience and Consciousness: Rousseau's Critique of the Stoic Theory of Oikeosis (2006), 1-33 [tutaj s. 3] <philosophy.fas.nyu.edu/object/philo.courses.ml06.html>, dostęp: 24.05.14. Por. termin conscience w: P. Brians, Common Errors in English Usage, Portland/OR: William, James \& Company, ${ }^{3} 2013$. Francuski tytuł książki D. Dennetta, Consciousness Explained (1991) brzmi La conscience expliquée (Paris: Odile Jacob, 1993).

5 Por. J. Bremer, Czy wolna wola jest wolna? Kompatybilizm na tle badań interdyscyplinarnych (Kraków: WAM, 2013), 328. Dodatkowo oprócz nieprawidłowości w rozwoju płatów czołowych socjopaci mają także zredukowane funkcje jądra migdałowatego. Struktury te są zaangażowane $\mathrm{w}$ uczenie się postaw społecznych. Socjopaci są ograniczeni w antycypacyjnej nauce bodziec - wzmocnienie, której wyniki są z kolei potrzebne do prawidłowego funkcjonowania brzuszno-przyśrodkowej kory przedczołowej (VMPFC) istotnej dla rozwoju normalnej moralnej socjalizacji. „Psychopaths are a kind of half informed homo economicus, [...] they do not hear the warning bells of conscience before they act [...]", M.B. Hoffman, The Punisher's Brain (N. York: Cambridge University Press, 2014), 116. 
jest ${ }^{6}$. Podobnie jest z rzeczownikiem „świadomy”, a zatem świadomość ma ilościowy sens, odnosząc się do stanu mentalnej aktywności jako przeciwnego stanowi nieświadomości, który może być spowodowany śpiączką, narkozą lub występować w czasie głębokiego snu. Możemy przyjąć prostą regułę, że jeśli pozostajemy świadomi, to z czystym sumieniem możemy powiedzieć, że znamy różnicę między tymi stanami.

\section{Filozoficzne teorie sumienia}

Zbudowana przez Arystotelesa etyka eudajmonistyczna odnosiła się do stanu pełnego, racjonalnie podbudowanego zadowolenia i satysfakcji z własnego życia. Osiągnięcie tego stanu było podstawowym celem każdego rozsądnego człowieka. Pojęcie sumienia w dzisiejszym znaczeniu nie występuje u Arystotelesa. Raczej używa on pojęcia dotyczącego właściwego wewnętrznego nastawienia (cnoty). Przeniesienie etyki Arystotelesa w czasy średniowiecza zawdzięczamy zasadniczo św. Tomaszowi z Akwinu. Dlatego mówimy o tomistycznej interpretacji etyki arystotelesowskiej ${ }^{7}$. Można powiedzieć, że najistotniejszymi tematami tomistycznej interpretacji etyki arystotelesowskiej są stwierdzenia, że: i) podmiotem życia moralnego jest człowiek widziany jako osoba, ii) podstawą etyki jest mądrość osoby, iii) sumienie jest podmiotową normą moralną, iv) przedmiotowe normy moralne pochodzą zasadniczo z prawa naturalnego.

Skupiając się na iii), należy wskazać na znany już Arystotelesowi dylemat: zasady etyczne są ogólne, a postępowanie osoby jest jednostkowe (tzn. decyzja osoby $\mathrm{X}$ jest konkretnie taka a taka). Tym samym sumienie oznacza podejmowanie danych decyzji na podstawie ostatecznych zasad. Arystoteles nie używał terminu „sumienie”, lecz „zamiar” (intentio) i odnosił go do zamiarów, które były ukryte w ludzkim wnętrzu, a więc nie podlegały

6 Problemy ze zdefiniowaniem świadomości w: J. Bremer, Jak to jest być świadomym. Analityczne teorie umysłu a problem świadomości (Warszawa: IFiS PAN, 2005), 21-25.

7 Por. Ch. Kranich-Strötz, Selbstbewusstsein und Gewissen: Zur Rekonstruktion der Individualitätskonzeption bei Peter Abaelard - Subjekt, Zeit, Geschichte (Berlin: LIT-Verlag, 2008), t. 2, 137-138. 
badaniom empirycznym ${ }^{8}$. Dla św. Tomasza sytuacja była odmienna, gdyż dla Boga nic nie było tajne. Dało to impuls do badań nad sumieniem. Dla eudajmonisty (i konwencjonalisty) św. Tomasza z Akwinu sumienie ogólne (syndereza, prasumienie) jest naturalną sprawnością (habitus naturalis) rozumu, jego sposobem postępowania'. Sprawność ta jest nam wrodzona, będąc trwałą jakością rozumu zachęcającą do czynienia dobra i zniechęcającą do czynienia zła. Jej zasadą działania jest znana zasada synderezy: bonum est faciendum malum vitandum ${ }^{10}$. Sumienie pełni dwie funkcje: oceniającą i nakazującą. Głos sumienia jest dla człowiekiem jeszcze przed popełnieniem czynu drogowskazem, natomiast po popełnieniu czynu - sankcją.

Etyka Arystotelesa i etyka św. Tomasza należą do paradygmatu etyki cnoty i różnią się od paradygmatu etyk skupiających się na normie (por. utylitaryzm czy deontologizm I. Kanta). Nie wchodząc tutaj w szczegóły nazewnictwa i drobiazgowe rozróżnienia, chcę jedynie dodać, że paradygmaty te różnią się między sobą ujęciem myślenia moralnego. Etyka Kanta jest nazywana etyką obowiązku albo etyką deontologiczną (gr. déon - obowiązek) i używa w swoich analizach pojęcia „sumienia”. I. Kant w Metafizyce moralności pisze, że sumienie posiada każdy człowiek

przed obserwującym go od wewnątrz sędzią odczuwa on respekt i lęk przeplatający się z szacunkiem. Ta czuwająca nad nim oraz jego prawem władza nie jest czymś ustanowionym przezeń dobrowolnie, lecz organiczną częścią jego istoty. Towarzyszy mu jak cień nawet wówczas, kiedy zdaje mu się, że udało mu się przed nią zbiec ${ }^{11}$.

Ujęcie sumienia jako wewnętrznego sędziego pojawia się także w Krytyce praktycznego rozumu, w której Kant pisze: „Z tym też zgadzają się orzecze-

8 Por. Ch. Kranich-Strötz, Selbstbewusstsein und Gewissen, 261-262, 268, 271.

9 Św. Tomasz z Akwinu, Summa theologiae (Romae: Marietti, 1952), I, q. 79, a. 12 „Patet ergo quod synderesis non est potentia, sed habitus naturalis".

10 Ibidem: „Unde et synderesis dicitur instigare ad bonum, et murmurare de malo” I, q. 79, a. 12; por. także, Summa theologiae, I, q. 5, a. 1 oraz a. 4 .

11 I. Kant, Metafizyka moralności (Warszawa: WN PWN, 2005), s. 315. Przekład: E. Nowak. Por. G. Nunner-Winkler, "Freiwillige Selbstbindung aus Einsicht - ein moderner Modus moralischer Motivation”, w: H.F. Klemme, M. Kühn, D. Schönecker (red.), Moralische Motivation: Kant und die Alternativen (Hamburg: Felix Meiner, 2006), 165-192 [172]. 
nia sędziowskie tej cudownej w nas władzy, którą nazywamy sumieniem”12. Cechą charakterystyczną tego paradygmatu etyki jest rozdzielenie osoby na dwie osobowości, przy czym ów sędzia jest przez Kanta konstruowany jako idealna osoba.

Eudajmonizm głosi, że czyn jest słuszny, jeśli prowadzi do szczęścia osoby, deontologizm natomiast mówi: postępuj według takiej zasady, co do której mógłbyś chcieć, aby stała się ona prawem powszechnym. Arystoteles i św. Tomasz nie skupiają się na normie i jej ogólnej ważności, lecz na dobru i cnocie. Deontologizm mówi, jakich norm mamy przestrzegać, eudajmonizm wskazuje, kim (jako osoby) mamy być.

Deontologia jest pokrewna z naszym potocznym ujmowaniem i przeżywaniem moralności. Stąd zainteresowanie nią ze strony współczesnych filozofów. Polegając na moralnych intuicjach, uważają oni, że to właśnie paradygmat deontologiczny najlepiej te intuicje obejmuje (osobną kwestią pozostaje, na ile tego typu deontyczne intuicje są racjonalne). Tak rozumianą deontologię przeciwstawia się dzisiaj nie tyle eudajmonizmowi, ile etycznemu konsekwencjonalizmowi: właściwe są te działania, których konsekwencje prowadzą do maksymalizacji dobra ${ }^{13}$. Konsekwencjonalizm wywodzi się $\mathrm{z}$ tradycyjnego utylitaryzmu ${ }^{14}$. Zgodnie z deontologią czyny są dobre w sobie, jeśli przebiegają według określonych zasad (np. imperatywu kategorycznego). Zasadnicze zarzuty skierowane przeciwko konsekwencjonalizmowi podkreślają, że jego konkretne aspekty nie współbrzmią z moralnością potoczną.

Dla eudajmonisty św. Tomasza oraz dla deontologa I. Kanta pojęcie sumienia ma ponadto religijne korzenie. Dzisiaj mało kto odwołuje się do takich źródeł i mówi o sumieniu tak podniosłym głosem, jak ci dwaj filozofowie. Nie znaczy to jednak, że głos sumienia jest przez współczesną naukę

12 I. Kant, Krytyka praktycznego rozumu (Warszawa: PWN), 1984, 161. Przekład: J. Gałecki.

13 Dokładne porównanie deontologii i konsekwencjonalizmu można znaleźć w M.W. Hallgarth, „Consequentialism and Deontology”, w: R. Chadwicks (red.), Encyclopedia of Applied Ethics (San Diego: Academic Press, 1996), t. 1, 609-621.

14 Np. dla G. Moore’a dobro jest pojęciem prostym i nie da się go ani zdefiniować, ani sprowadzić do kryteriów „naturalnych”. Konwencjonalistyczna i utylitarystyczna etyka brytyjska XIX-XX w. jest konsekwencjalistyczna (o moralnej kwalifikacji czynu decydują skutki - konsekwencje). Por. T. Biesaga, „Konsekwencjonalizm,” w: Powszechna encyklopedia filozoficzna, (Lublin: KUL, Polskie Towarzystwo Tomasza z Akwinu, 2004), t. 5, 801-803. 
lekceważony. Z jednej strony rzadko neguje się, że jest coś takiego jak głos sumienia, że musimy czasami przemówić komuś do sumienia. Z drugiej strony prawie nikt nie mówi, czym sumienie faktycznie jest. Nie jest to głos Boga, głos rozumu - czyim głosem zatem jest sumienie?

\section{Neurofilozoficzne teorie sumienia}

Według P. Churchland, neurobiologiczną rzeczywistością leżącą u podstaw naszego rozumienia sumienia jest schemat reakcji społecznych, ukształtowany w wieku dziecięcym na bazie interakcji między mózgiem, genami a środowiskiem. „Jednak sumienie, oderwane od neurobiologii uspołecznienia i społecznego uczenia się, rozumiane jako metafizyczny byt posiadający wiedzę moralną, pozbawione jest podstaw”"15. Jedną z trudności, jaką Churchland dostrzega w mówieniu o sumieniu, jest to, że - jako głos wewnętrzny -nie doradza nam ono zawsze w ten sam sposób. Podawane przez sumienie wskazania różnią się nie tylko w przypadku różnych osób, lecz także w przypadku jednej osoby - jej wewnętrzny głos często podpowiada odmienne rozwiązania moralne w odmiennych okolicznościach.

Skąd bierze się moralność? Churchland widzi jej źródło w biologii mózgu. Opisuje ona neurobiologiczną podstawę powiązania neuronów, która modyfikowana naciskami ewolucyjnymi oraz wartościami kulturowymi doprowadziła do ludzkich stylów moralnych zachowań. Wartości moralne, według Churchland, są zakorzenione w zachowaniu powszechnym dla wszystkich ssaków - trosce o potomstwo. Chemia ludzkiego umysłu skłania nas do dokładania starań o utrzymanie siebie, a także o zapewnienie utrzymania i przeżycia naszemu potomstwu, a następnie naszym partnerom, krewnym i coraz większemu kręgowi innych osób. Separacja i wykluczenie z tych kręgów wywołuje ból, towarzystwo przyjaznych osób wywołuje przyjemność. Mózgi modyfikują swoje obwody odpowiednio do lokalnych

15 P. Churchland, Moralność mózgu. Co neuronauka mówi o moralności (Kraków: Copernicus Center Press, 2013), 309 [por. 308-311]. Przekład: M. Hohol. Tytuł oryginału: P. Churchland, Braintrust: What Neuroscience Tells Us about Morality (Princeton: Princeton UP, 2011). 
zwyczajów kulturowych. W ten sposób troska jest porozdzielana, sumienie formowane, a moralne intuicje są nam wpajane. Istotną rolę w procesie uspołeczniania i przywiązywania do innych odgrywa hormon zwany oksytocyną (OXT), który pojawił się dużo wcześniej niż ssaki ${ }^{16}$. Zmniejszając odpowiedzi na stres, OXT pozwala nam rozwijać troskę o innych, konieczną z kolei do rozwoju instytucji społecznych i moralności.

Z neurobiologicznej perspektywy sumienie jest

schematem reakcji, który w dużej mierze kształtuje się podczas interakcji między mózgiem, genami a środowiskiem, gdy dziecko wkracza w życie społeczne. Jednak sumienie, oderwane od neurobiologii uspołecznienia i społecznego uczenia się, rozumiane jako metafizyczny byt posiadający wiedzę moralną, pozbawione jest podstaw ${ }^{17}$.

Pozostawiając na boku dywagacje Churchland o „metafizyce sumienia”, chcę wskazać na inny słaby punkt jej teorii świadomości - na próbę wyjaśnienia natury i pochodzenia zachowań moralnych przez odwołanie się do wyników badań naukowych. Projekt ten jest w całości opisowy i brak mu normatywnych zobowiązań. Z jednej strony można postawić zarzut, że Churchland pozostawia to pojęcie niewyjaśnione. Z drugiej strony, broniąc Churchland, można na ten zarzut odpowiedzieć, że jej książka nie jest o tym, jakie działania są właściwe, czy też jakie stany rzeczy są dobre, lecz jest ona raczej o tym, jakie neurobiologiczne cechy umożliwiają moralne zachowania ludzi. Tezy takiej można się dopatrzyć w jej stwierdzeniu, że filozoficzne poszukiwanie silniejszych form argumentów przemawiających za normatywną prawdą moralną prowadzi do „metafizyki” i do „platońskiego nieba”. Churchland przyjmuje jedynie alternatywę: albo wartości pochodzą od ludzi i ich mózgu, albo z platońskiego nieba ${ }^{18}$. Lecz tak postawiona dychotomia pomiędzy redukcyjnym naturalizmem a supernaturalizmem w etyce nie jest przekonująca. Liczni filozofowie próbują ustalić formy

16 Por. P. Churchland, Moralność mózgu, 88-90.

17 Ibidem, 309.

18 „Nie istnieje Platońskie niebo, w którym rezydują prawdy moralne - nie jest ono bardziej rzeczywiste niż Platońskie niebo prawd fizykalnych”, ibidem, 293. 
moralnego nie-naturalizmu, który nie jest sprzeczny z naturalistycznym widzeniem świata i który nie twierdzi, że cechy moralne są czymś tajemniczym (misteriańskim). Próby takie znajdujemy na przykład w pracach quasi-realisty S. Blackburna ${ }^{19}$. Ani nie odwołuje się on do platońskiego nieba, ani nie uważa, że poprawność zdań normatywnych zależy li tylko od budowy ludzkiego mózgu. Fakty normatywne to fakty o naszych racjach i sensowne wydaje się mówienie o racjach bez zakładania, że muszą one być platońskiego pochodzenia.

Kilka uwag krytycznych:

1) Churchland przyjmuje, że niektóre instytucje i praktyki postępowania są lepsze dla społeczeństwa, gdyż gwarantują stabilność, wzrost i ogólnie pozwalają na rozkwit społeczeństwa. Niemniej jednak trudno będzie wyjaśnić, dlaczego powinniśmy się troszczyć o te cechy społeczeństwa bez odniesienia się do tradycyjnych pojęć moralnych, takich jak sprawiedliwość, postęp, równość. Dlaczego mielibyśmy się np. angażować czy opowiadać za przyznaniem praw mniejszościom narodowym? Churchland odpowiedziałaby, że troska o równość społeczną czyni społeczeństwo bardziej stabilnym. Dlaczego jednak powinniśmy się o to troszczyć? Czy Churchland nie ma nic do powiedzenia radykalnym jednostkom, które twierdzą, że ucisk i prześladowanie mniejszości jest dobrem samym w sobie? Z jednej strony osoby te cenią społeczną stabilność i postęp społeczeństwa, a z drugiej strony nie zgadzają się z Churchland co do rozumienia rozkwitu społeczeństwa. Osoba taka może się nie zgadzać, że egalitarne społeczeństwo jest takim, które rozkwita.

2) Żaden filozof moralności nie powinien mieć problemu z przytaczanymi przez Churchland stwierdzeniami o mózgu ssaków bądź o neurotransmiterach. Napięcie pojawia się wtedy, gdy ekstrapoluje ona te wyniki na moralność i twierdzi, że owe biologiczne mechanizmy wyjaśniają ludzką moralność.

19 Por. np. quasi-realistyczny projekt połączenia naturalizmu i moralnego realizmu zaproponowany przez S. Blackburna w jego: How To Be an Ethical Anti-Realist. Essays in Quasi-Realism (New York: Oxford UP, 1993). 
3) Churchland wydaje się przekonana, że proste praktyki i zachowania, o których mówi, są tymi, które większość ludzi uważa za moralne. Zaznacza ponadto, że powinny zostać uruchomione procedury dotyczące rozumienia źródeł zachowań moralnych. Lecz to nie znaczy jeszcze, że cel owych procedur ma być wyprowadzony z tych zachowań. Czy np. fakt empiryczny, że ludzie działają bardziej egoistycznie, gdy nikt nie widzi, znaczy, że zawsze mamy mieć zapalone światło i przyjmować inne reguły dla działania w nocy?

4) Churchland uważa, że pomimo naszej niezdolności do wyprowadzenia „powinien” z „jest” potrafimy jakoś określić, jak powinniśmy postępować. Niemniej jednak ani nie wyjaśnia ona, jak taki stan może zostać osiągnięty, ani nie zauważa, że ostatecznym problemem nie jest wyjaśnienie zachowań, lecz ich usprawiedliwienie (uzasadnienie). Należy się cieszyć, że firmy farmaceutyczne nie odkryły moralnego znaczenia ani korzyści płynących z funkcjonowania naszych OXT-receptorów. Gdyż wówczas troska o potomstwo czy o najbliższych przestałaby być wartością moralną.

\section{Empiryczne badania potocznych ocen moralnych}

Czy na pytanie „czyim głosem jest głos sumienia?” można szukać kognitywistycznych odpowiedzi, posiłkując się głównie neuronaukami? To znaczy badaniami nad tym, jak „głos sumienia” wyłania się lub jest skorelowany z aktywnością mózgu. Neuronauki (neurosciences) są kompleksową i stosunkowo młodą, interdyscyplinarną gałęzią nauki, łączącą w sobie badania nad strukturą oraz funkcjonowaniem systemu nerwowego. Ich przedstawiciele zamierzają wyjaśnić funkcjonowanie poznawczego, emocjonalnego i społecznego zachowania ludzi na podstawie badań funkcjonowania mózgu. Neuronauki odwołują się do wiedzy z zakresu neurobiologii, neurofizjologii, neuropsychologii oraz neuroobrazowania. Uprawiający je naukowcy za jeden ze swoich celów uważają poszukiwanie neuronalnych korelatów świadomych stanów podmiotu (myśli i uczuć), korelatów podejmowanych przez podmiot decyzji oraz oceniania tych- 
że decyzji ${ }^{20}$. Używają przy tym nowoczesnych technik neuroobrazowania mózgu (elektroencefalografii - EEG; rezonansu magnetycznego - MRI; funkcjonalnego rezonansu magnetycznego - fMRI; tomografii pozytronowej - PET) ${ }^{21}$.

Od razu, podobnie jak przy tezach Churchland, pojawia się jednak wątpliwość: czy neuronauki nie pozostawią na boku tego, co nie odpowiada ich empirycznej metodologii postępowania? Czy nie pozostawią na boku np. społecznego elementu, obecnego w sumieniu, który zarówno dla św. Tomasza, jak i dla Kanta czy Churchland był istotny dla rozumienia sumienia. Głos sumienia bazuje na potrzebie uznania ze strony innych ludzi i na tym, że my im takie uznanie przyznajemy. Chcę zaznaczyć, że jeśli do poszukiwania odpowiedzi na pytanie o źródła głosu sumienia używamy tomografii komputerowej, to nie oznacza to, że usuwamy zasadnicze pytania stawiane przez filozofów lub że od razu staramy się je zredukować do aktywności określonych grup neuronów. Wychodzimy jednak z założenia, że mogą występować sytuacje graniczne, gdzie ważne okaże się dostrzeżenie, co zachodzi w mózgu (co zostało w nim ewolucyjnie zaimplementowane) i co jest godne uwagi z punktu widzenia pojęć filozoficznych. Tym samym badania mózgu i uzyskane w nich wyniki mogą wejść w owocny dialog z filozoficznymi i potocznymi pytaniami o sumienie.

Neuronaukowcy traktujący swoje badania bardzo wąsko mogą być skłonni do pomijania owego społecznego aspektu sumienia, co zachodzi wówczas, kiedy zazwyczaj badają oni jedynie pojedyncze, wyizolowane mózgi. Musimy się zwrócić do neuronaukowców otwartych na współpracę w ramach badań interdyscyplinarnych. Stąd nadzieja, że interdyscyplinarne podejście do pytania o sposób funkcjonowania sumienia może spowodować, że i) stanie się ono obszarem badań teoretyczno-eksperymentalnych, ii) uda nam się zapobiec zbyt szybkiej, wąsko rozumianej redukcji pytania

20 Por. G. Raab, O. Gernsheimer, M. Schindler, Neuromarketing: Grundlagen - Erkenntnisse Anwendungen (Wiesbaden: Gabler Verlager, 2009), 2-3; por. R. Stach, A.M. Popek, „Decyzje ekonomiczne i społeczne z perspektywy pogranicza neuronauk oraz nauk o zarządzaniu,” International Journal of Contemporary Management 2/13 (2013), 48-57 [49-50].

${ }^{21}$ Techniki te zostały dokładnie omówione w: J. Bremer, „Czym jest neuromarketing?,” Communication Today 1/4 (2013), 18-34 [21-24]. 
o sumienie do procesu odpalania neuronów w jakimś obszarze mózgu. Powstanie tym samym sytuacja znana z badań kognitywistycznych, w której filozofowie, psychologowie, socjologowie, a także neurolodzy mają swoje miejsce i każdy z nich może wnieść wyniki swoich badań, a żaden nie będzie sobie uzurpował prawa do udzielenia jedynej właściwej odpowiedzi na zadane pytanie o to, czyim głosem jest sumienie.

Współcześni psychologowie moralności, kognitywiści oraz neuronaukowcy przeprowadzili liczne badania empiryczne, zmierzające do ustalenia neuronalnych podstaw oraz struktur potocznych ocen moralnych. Dzięki tym badaniom odkryto chociażby swoistą zależność: jeśli sytuacja moralna domaga się osobistego wyrządzenia komuś krzywdy, to najczęściej orientujemy się według rozstrzygnięć deontologicznych, jeśli natomiast analizujemy abstrakcyjne, nieosobiste działania, to orientujemy się według rozstrzygnięć konsekwencjonalistycznych. Niżej przedstawię i poddam krytycznej analizie kilka tego typu badań empirycznych.

Przy tak postawionym zagadnieniu należy zbadać trzy aspekty: i) emocje moralne, ii) zdolność do wczucia się w myślenie i odczuwanie innych ludzi, iii) myślenie abstrakcyjne nad sytuacjami moralnymi. Badania neuronaukowców, prowadzone z różnych stron, przyczyniają się do ustalenia, jak te różne aspekty są skorelowane z procesami zachodzącymi w rozmaitych regionach mózgu.

\subsection{J. Greene: neuroobrazowanie mózgu w czasie rozważania dylematów moralnych}

Rodzaj badań empirycznych, o który mi tutaj chodzi, prowadzi od lat filozof i psycholog J. Greene z uniwersytetu w Princeton. Osoba X zostaje umieszczona w tomografie komputerowym i na odpowiednim ekranie ma przeczytać następujące dwa opowiadania ${ }^{22}$. W pierwszym z nich X właśnie kieruje rozpędzoną drezyną i krótko przed zwrotnicą widzi, że wjedzie na

${ }^{22}$ Por. J. Greene, “The Secret Joke of Kant's Soul,” w: W. Sinnott-Armstrong (red.), Moral Psychology, t. 3: The Neuroscience of Morality: Emotion, Brain Disorders, and Development, Cambridge/MA, and London: MIT Press, 2007, 35-79 [tutaj 41-42]. 
lewy tor, na którym pracuje pięciu robotników kolejowych. Nie dostrzegają oni pędzącej drezyny i nie będą w stanie odsunąć się od toru. Jeśli X nie podejmie żadnych działań, to zabije wszystkich pięciu robotników. Może jednak przerzucić zwrotnicę i wjechać na prawy tor. Tam pracuje jeden robotnik, który zginie. Wiodące pytanie brzmi: jak postąpi X wobec stojącego przed nim moralnego dylemat? Czy jest uzasadnione zabić jednego człowieka, aby uratować pięciu?

W drugim opowiadaniu ponownie rozpędzona drezyna zmierza ku torowi, na którym pracuje pięciu robotników. Teraz jednak X znajduje się na kładce dla pieszych przewieszonej nad torem kolejowym, po którym pędzi drezyna. Obok X, dokładnie nad torem, stoi bardzo gruby, obcy człowiek. Jeśli X natychmiast popchnie tego człowieka, a ten spadnie na tor przed drezyną, to drezyna się zatrzyma. Człowiek ten zginie, lecz pięciu robotników zostanie uratowanych. Greene’a ponownie interesuje, jak postąpi X lub jak my byśmy postąpili w tej moralnie trudnej sytuacji ${ }^{23}$.

Interesujące wyniki uzyskano dzięki neuroobrazowaniu mózgu X (i innych osób) za pomocą tomografii komputerowej. Jeśli badane osoby jedynie rozważały, czy mają przestawić zwrotnicę, to aktywne były głównie przednie części kory mózgu, odpowiedzialne za logiczne myślenie oraz porównywanie różnych informacji. Jeśli jednak badane osoby myślały nad tym, czy zepchnąć z mostu grubego osobnika, aktywowały się u nich także dodatkowe obszary mózgu. Na przykład obszary ewolucyjnie starsze, należące do tzw. układu (systemu) limbicznego ${ }^{24}$. Układ ten jest między innymi odpowiedzialny za pojawianie się takich emocji, jak osłupienie, przerażenie, lęk czy smutek. Po przebadaniu wielu osób Greene doszedł do wniosku, że nasze decyzje moralne mają często emocjonalną, instynktowną

23 Wg Greene'a: „People exhibit a characteristically consequentialist response to the trolley case and a characteristically deontological response to the footbridge case”, ibidem, 42.

24 Na układ ten składają się różne części kory starej i nowej (hipokamp, zakręt zębaty, zakręt hipokampa, zakręt obręczy, pole śródwęchowe i przegrodowe, ciało migdałowate). Układ ten umożliwia wymianę bodźców między strukturami umiejscowionymi w śródmózgowiu, międzymózgowiu oraz korze nowej. Zakłada się, że jest on powiązany z doznaniami afektywnymi lub z afektywnym i instynktownym zachowaniem ogólnym. Por. P. Duus, Diagnostyka topograficzna w neurologii (Warszawa: Państwowy Zakład Wydawnictw Lekarskich, 1989), 245, 267-270. 
podstawę. Ujawnia się ona tym silniej, im bardziej nasze moralne decyzje są bezpośrednio skonfrontowane lub dotyczą losu innych ludzi. Podobną koncepcję do Greene’owskiej przedstawił w filozofii już D. Hume, zdaniem którego to emocje określają świat naszych ludzkich decyzji moralnych i skłaniają nas do działania ${ }^{25}$. Wśród kognitywistów brak jednak zgody co do tak zasadniczo rozumianej roli emocji.

\subsection{Inne badania}

A) W badaniach przeprowadzonych przez M. Koenigsa, L. Younga [oraz innych] przejęto wyprowadzoną przez Greene’a hipotezę o trudnościach związanych z określeniem neuronalnego podłoża przy rozwiązywaniu dylematów moralnych. Przebadano sześć osób z uszkodzoną brzuszno-przyśrodkową korą przedczołową (ventromedial prefrontal cortex, VMPFC) ${ }^{26}$. Okazało się, że w przypadkach trudnych konfliktów moralnych były one bardziej skłonne aniżeli osoby z nieuszkodzoną brzuszno-przyśrodkową korą przedczołową zgodzić się na wyrządzenie komuś szkody celem uzyskania większego dobra ${ }^{27}$. Według Koenigsa i Young te wyniki stanowią poparcie dwóch hipotez: i) sąd moralny jest podwójnym systemem procesów, składającym się z „intuicyjno-afektywnych” i „świadomie racjonalnych” mechanizmów, ii) absolutne zaniechanie wyrządzenia komuś szkody zależy od sprawnie funkcjonującego systemu afektywnego lub emocjonalnego. Tak więc również te badania zdają się łączyć emocje z „deontologicznymi” sądami moralnymi lub

25 „Myślę, że można ustalić, pewnie jako regułę ogólną, że wszelka rzecz, która ukazuje się naszym zmysłom i wszelki obraz, który tworzy się w wyobraźni, musi łączyć się z jakimś wzruszeniem czy poruszeniem humorów, odpowiednio silnych", D. Hume, Traktat o naturze ludzkiej (Warszawa: PWN, 1963), II, II, 8 [135]. Przekład: Cz. Znamierowski.

26 VMPFC należy do struktur zaangażowanych w analizę, ekspresję, kontrolę emocji. Hamuje zachowania społecznie naganne. Por. W. Duch, „Emocje i układ limbiczny,” <http://www. fizyka.umk.pl/ duch/Wyklady/Mozg/07-3-limbiczny.htm>, dostęp: 26.07.14.

27 „Patients with VMPC lesions exhibit generally diminished emotional responsivity and markedly reduced social emotions (for example, compassion, shame and guilt) that are closely associated with moral values”, M. Koenigs, L. Young, R. Adolphs, D. Tranel, F. Cushman, M. Hauser, A. Damasio, "Damage to the Prefrontal Cortex Increases Utilitarian Moral Judgments," Nature 446 (2007), 908-911 [908]. 
poznanie z sądami „utylitarystycznymi” (gdy chodzi o dopuszczalność wyrządzania szkody innym osobom).

B) F.-X. Neubertemail, R.B. Mars [i inni] twierdzą, że udało im się zidentyfikować obszar w ludzkim mózgu, który nie występuje u innych prymatów ${ }^{28}$. Obszar ten funkcjonuje jak głos z wewnątrz, popularnie zwany sumieniem. Głos ten mówi nam, kiedy pobłądziliśmy i postępujemy źle oraz kiedy roztropniej byłoby uczynić coś dobrego. Obszar ten należy do brzuszno-bocznej kory czołowej (ventrolateral frontal cortex, vlFC), która jest zaangażowana w najbardziej złożone (wyższe) procesy poznania i w procesy opanowania języka. Za pomocą MRI zostało przebadanych 25 osób i 25 makaków. Badania te potwierdzają, że sumienie jest specyficzną ludzką własnością.

C) U badanych osób, które rozważały sytuację z grubym człowiekiem na moście, aktywizowały się także regiony mózgu leżące ponad uszami. Zbierają one informacje o innych ludziach przez to, że rejestrują, w jaki sposób ludzie ci poruszają swoimi oczami, rękami czy ustami. Zdolność do wczucia się w sytuację drugiego człowieka jest zakorzeniona w sieciach neuronowych mózgu, na co wskazują np. badania przeprowadzone przez T. Singer, B. Seymoura [i innych $]^{29}$. Upraszczając nieco, można omawiane badania przedstawić następująco. Osoba X leży w funkcjonalnym rezonansie magnetycznym (fMRI), a osoba jej bliska siedzi obok niej. Osoba X zostaje podana lekkiemu elektrowstrząsowi i urządzenie rejestruje, jakie regiony bólowe jej mózgu zostają aktywowane. Następnie na umieszczonym wewnątrz fMRI ekranie X widzi, że siedząca obok niej osoba także zostaje poddana elektrowstrząsowi. Chociaż sama nie odczuwa w tym momencie żadnego bólu, niektóre bólowe regiony jej

28 Por. F.-X. Neubertemail, R.B. Mars, A.G. Thomas, J. Sallet, M.F.S. Rushworth, “Comparison of Human Ventral Frontal Cortex Areas for Cognitive Control and Language with Areas in Monkey Frontal Cortex," Neuron 3/81, (2014), 700-713.

29 „We used functional magnetic resonance imaging (fMRI) to explore both common and unique brain circuitry involved when we experience pain in ourselves, as well as when we observe someone else feeling pain”, T. Singer, B. Seymour, J. O’Doherty, H. Kaube, R.J. Dolan, Ch.D. Frith, "Empathy for Pain Involves the Affective but not Sensory Components of Pain,” Science 303 (2004), 1157-1162 [1158]. 
mózgu zostają na nowo zaaktywowane. Oczywiście nie te regiony, które informują, gdzie w organizmie X występuje ból i jak jest on silny, lecz te, które odzwierciedlają odczuciowy aspekt bóluº

Zarówno ból, jak i wczucie się w sytuację innej osoby są przez X odczuwane. Być może w podobny sposób można analizować sumienie. Osobę X można zapytać, co odczuwała, gdy niesłusznie została skrzywdzona, gdy uczyniła komuś coś złego lub gdy z lęku zaniechała jakiegoś działania. W ten sposób można by się dużo dowiedzieć o korelatach sumienia.

D) Część badań skupia się na regionie mózgu leżącym ponad oczodołami - tzw. korze oczodołowej czołowej (orbitofrontal cortex, OFC) ${ }^{31}$. Należy ona wprawdzie jeszcze do systemu limbicznego, lecz leży na jego zewnętrznym brzegu, łącząc ten system z wyższymi obszarami kory odpowiedzialnymi za myślenie racjonalne. Ludzie, u których kora ta jest uszkodzona, zachowują się najczęściej aspołecznie i niemoralnie, nie wykazując szacunku dla drugiego człowieka. Mają problemy z poprawnym identyfikowaniem sygnałów społecznych obejmujących między innymi prawidłowe odczytanie wyrazu twarzy czy jakościową identyfikację wyrażenia głosowego (np. po tonie wypowiedzi). Klasycznym przykładem osoby z uszkodzoną korą oczodołowo-czołową jest Phineas Gage, opisany przez A. Damasio w książce Błąd Kartezjusza ${ }^{32}$. Jeśli uszkodzenie nastąpiło w dorosłym wieku, to pojawiają się zmiany w emocjach, osobowości i zachowaniach, niemniej jednak jego ograniczające skutki nie

30 „Nevertheless, the results of the present study and previous investigations suggest a segregation of sensory-discriminative and autonomic-affective attributes of the pain experience. Rostral ACC (anterior cingulate cortex) and AI (anterior insula) appear to reflect the emotional experience that evokes our reactions to pain and constitutes the neural basis for our understanding of the feelings of others and ourselves", T. Singer, B. Seymour [i in.], "Empathy for Pain Involves the Affective but not Sensory Components of Pain," 1160.

31 „[OFC] can be defined as the part of the prefrontal cortex that receives projections from the magnocellular, medial, nucleus of the mediodorsal thalamus", M.L. Kringelbach, E.T. Rolls, "The Functional Neuroanatomy of the Human Orbitofrontal Cortex: Evidence from Neuroimaging and Neuropsychology,” Progress in Neurobiology 72 (2004), 341-372 [343].

32 A.R. Damasio, Błąd Kartezjusza. Emocje, rozum i ludzki mózg (Poznań: Rebis, 2011). Przekład: M. Karpiński. 
są tak silne, jak wtedy, gdy uszkodzenie nastąpiło w wieku dziecięcym. Dzieci obarczone takim brakiem w zasadzie nie są w stanie rozwinąć w sobie postaw moralnych. Co wskazuje, że OFC jest nie tylko ważne dla działania na bazie sumienia, lecz także odgrywa istotną rolę w tworzeniu sumienia ${ }^{33}$. OFC stanowi krytyczną strukturę w neuronalnym systemie służącym podejmowaniu decyzji. Podejmowanie decyzji nie jest mediowane jedynie przez OFC, lecz wynika z dużej skali systemów zawierających inne komponenty korowe i podkorowe. Struktury te, jak wspomniałem wyżej, obejmują jądra migdałowate, korę somatosensoryczną, wyspę i obwodowy układ nerwowy. Tutaj skupiamy się jedynie na ukazaniu roli OFC w podejmowaniu decyzji i w procesach emocjonalnych oraz na analizie innych funkcji kognitywnych w płacie czołowym.

Można powiedzieć, że OFC jest zaangażowana w podejmowanie rozstrzygnięć sumienia, nie jest jednak jasne, w jaki sposób jest ona połączona $\mathrm{z}$ innymi regionami systemu limbicznego.

E) W poszukiwaniach neuronalnych korelatów sumienia musimy także uwzględnić rolę pamięci, zwłaszcza długotrwałej. Magazynuje ona nie tylko wyuczone reguły moralne, lecz także te doświadczenia, które ktoś zdobył na podstawie decyzji i osądów swojego sumienia. Ponadto należałoby uwzględnić regiony przednie w mózgu, które regulują siłę woli ${ }^{34}$. Określają one bowiem, jak dalece decyzje sumienia są podtrzymywane w czasie, np. gdy są niezgodne z normami społecznymi.

33 Por. J.L. Hanson, M.K. Chung, B.B. Avants, E.A. Shirtcliff, J.C. Gee, R.J. Davidson, S.D. Pollak, "Early Stress Is Associated with Alterations in the Orbitofrontal Cortex: A Tensor-Based Morphometry Investigation of Brain Structure and Behavioral Risk," The Journal of Neuroscience 22/30 (2010), 7466-7472. Po przebadaniu grupy 72 dzieci (z których 31 doznawało w dzieciństwie fizycznego znęcania się) uzyskane wyniki wskazują na to, że objętość OFC jest mniejsza u dzieci, które cierpiały z powodu niezrównoważonych rodziców. Braki w rozwoju OFC były kojarzone z trudnościami owych dzieci w przeżywaniu różnych aspektów życia społecznego. „The oFC is a key component of a circuit that aids in adaptation to changing environmental contingencies and plays an important role in the control of emotion and motivational states. The structural alterations that we observed in abused childrens' oFC may lead to functional difficulties for these children, compromising their abilities to navigate in and adaptively regulate to changing social contexts", ibidem, 7470.

34 Por. eksperymenty J.-D. Haynesa np. w: J. Bremer, Czy wolna wola jest wolna?, 227-241. 


\section{Interpretacje wyników}

Analizując neuronaukowe wyniki uzyskane przez Greene’a, można wprowadzić dwie płaszczyzny, potrzebne do analiz sumienia. Pierwsze to sumienie instynktowne, które zawdzięczamy ewolucji biologicznej, a którego neuronalne korelaty występują w układzie limbicznym. W tym wypadku chodzi najczęściej o prostą, prymitywną reakcję na jakąś sytuację. Widząc, że małe dziecko za chwilę wpadnie pod samochód, nie będziemy zbyt wiele myśleć, zastanawiać się nad konsekwencjami (także dla nas samych), lecz spróbujemy to dziecko uratować. Coś innego zachodzi przy bardziej złożonych emocjach, które są dodatkowo sterowane przez wyższe procesy korowe. Sumienie w tak złożonych, emocjonalnych aspektach jest naznaczone kulturowo, ale sumienie kulturowe ma także instynktowną podstawę, której nie należy ignorować. Eksperymenty Greene’a mówią także coś o tym, jak czuły się osoby, kiedy rozważały pytanie: czy faktycznie mogę poświęcić jedną osobę, aby uratować pięć innych? Osoby, które zdecydowały się pchnąć grubego człowieka pod drezynę, potrzebowały więcej czasu aniżeli te, które nie mogły się do tego czynu przełamać35. Musiały one prawdopodobnie pokonać ewolucyjnie starsze, instynktowne, wewnętrzne opory.

Czy wyniki uzyskane przez Greene’a i innych pozwalają na stwierdzenie, że odkryli oni neuronalne podstawy sumienia czy wyrzutów sumienia? Czy można powiedzieć, że tym samym neuronauki wyeliminowałyby deontologię, czyli część etyki zajmującej się obowiązkami moralnymi oraz tym, co decyduje o moralnej wartości czynów? ${ }^{36}$ Czy wyniki empiryczne przemawiają przeciw deontologicznej koncepcji sumienia? Greene twierdzi, że kilka badań aktywności mózgu za pomocą fMRI w czasie podejmowania decyzji moralnych przemawia przeciwko słuszności deontologii jako teorii

35 „That means that someone who judges a personal moral violation to be appropriate (e.g., someone who says it's okay to push the man off the bridge in the footbridge case) will most likely have to override an emotional response in order to do it. This overriding process will take time, and thus we would expect that «yes» answers will take longer than «no» answers in response to personal moral dilemmas like the footbridge case”, J. Greene, “The Secret Joke of Kant's Soul," 44.

36 Greene uważa, że: „Deontology, I believe, is a natural «cognitive» expression of our deepest moral emotions", ibidem, 63. 
moralnej. Badania za pomocą fMRI pokazują, że deontologiczne myślenie wyłania się z regionów mózgu bardziej skojarzonych z „emocjonalnymi” reakcjami, podczas gdy myślenie utylitarystyczne wyłania się z bardziej „kognitywnych” regionów, takich jak kora przedniej części zakrętu obręczy i grzbietowo-boczna kora przedczołowa (DLPFC). Greene uważa, że wszystkie jego kierunki badań sugerują silne powiązanie pomiędzy odpowiedziami emocjonalnymi a deontologicznymi sądami moralnymi ${ }^{37}$. Deontologiczna teoria - a wraz z nią jej pojęcie sumienia - jest rodzajem racjonalizacji reakcji emocjonalnych „po fakcie”, a tym samym zawodnym przewodnikiem moralnym, gdyż reakcje emocjonalne rozwinęły się w warunkach moralnie różnych od tych, z którymi większość z nas codziennie się styka.

Chociaż konsekwencjonalizm także jest filozoficznym odwzorowaniem neuronalnych aktywności, to opiera się on bardziej na kognitywnych aniżeli na emocjonalnych procesach w systemie nerwowym; tym samym pozwala on na bardziej elastyczne zachowania, które z kolei są odpowiedziami na moralne rozważania, zamiast być refleksyjnymi reakcjami mogącymi odciągać działającą osobę od refleksji nad moralnie znaczącymi cechami danej sytuacji. Teorie konsekwencjonalistyczne cechują się dwoma atrakcyjnymi aspektami: a) obecny w nich utylitarystyczny rachunek korzyści jest procesem racjonalnym, niezależnym od wielkości metafizycznych (bez Boga czy sumienia jako gwarantów moralności). Decyzje moralne zakładają racjonalne rozważania, które każda osoba może przeprowadzić, co odpowiada naszemu pooświeceniowemu społeczeństwu i sposobowi myślenia; b) zasady utylitarystyczne także odpowiadają naszym moralnym intuicjom, tzn. że skutki powinny odgrywać rolę przy ocenie działania, a te są dobre, gdy są pożyteczne.

Będę się starał zakwestionować stanowisko Greene’a, twierdząc, że: a) wyniki badań empirycznych, na które Greene się powołuje, nie wzmacniają wniosku, że teoria deontologiczna jest rodzajem racjonalizacji moralnie zawodnych reakcji emocjonalnych „po fakcie” oraz że b) tym samym

$37,[\ldots .$.$] essentially, is an attempt to produce rational justifications for emotionally driven$ moral judgments and not an attempt to reach moral conclusions on the basis of moral reasoning”, ibidem, 39. 
teoria deontologiczna nie jest gorsza/słabsza od konsekwencjonalistycznej teorii moralnej. Greene powołuje się na wspomniane już dwa rodzaje aktywności neuronalnej zaangażowane w osądzanie moralne: „procesy emocjonalne”, które kojarzy z sądami deontologicznymi, i „procesy poznawcze”, które kojarzy z moralnymi sądami konsekwencjonalistycznymi. Do podobnych wyników prowadzą badania Koenigsa.

Kilka filozoficznych uwag do wniosków wyciąganych przez Greene’a:

1) Przyjmując uzyskane przez niego wyniki i podział na procesy emocjonalne i kognitywne, nadal nie można przewidzieć treści teorii deontologicznych ze schematów reakcji emocjonalnych. Bez tego typu silnej teorii identyczności (lub przynajmniej silnej współzmienności ${ }^{38}$ ) neuronauki nie dostarczą nam jednoznacznej racji za przyjęciem tezy Greene’a, że etyczne teorie deontologiczne są mniej uzasadnione aniżeli teorie konsekwencjonalistyczne.

2) Nie mamy jednej jedynej teorii deontologicznej. Niemniej jednak jakakolwiek teoria moralna musi objąć o wiele szersze spektrum przypadków aniżeli analizowane przez Greene’a dylematy moralne. Greene stwierdza, że zidentyfikowane przez niego odpowiedzi emocjonalne dotyczą jedynie przypadków braku osobistych korzyści, więc odpowiedzi te nie mogą przewidzieć, co jakaś teoria powie o innych przypadkach.

3) Greene wskazuje na Kanta jako przedstawiciela teorii deontologicznych. Trudno jednak uznać, że u podstaw teorii Kanta leżą intuicje kierowane emocjami. Podkreśla ona raczej ważność moralnego obowiązku, będącego ponad systemem przyrody, a sama moralność musi być zbudowana na zasadach racjonalnych leżących poza przewidywalną przyczynowością praw przyrody ${ }^{39}$. Greene nie uwzględnia roli sumienia, owego wewnętrznego sędziego, w deontologii Kanta.

4) Powiedzmy, że inaczej aniżeli Greene, uwzględnimy dłuższy czas odpowiedzi (jak to się dzieje w wielu potocznych rozważaniach ko-

38 Chodzi tutaj np. o silną współzmienność (korelację) obecną w niektórych teoriach superweniencji, por. J. Bremer, Wprowadzenie do filozofii umysłu (Kraków: WAM, 2010), 160.

39 Por. M.W. Hallgarth, „Consequentialism and Deontology,” 615-616. 
gnitywnych) i krótszy czas reakcji (jak to jest w czysto automatycznie podejmowanych decyzjach). Wówczas pojawią się dodatkowe problemy z pytaniem, czy osoby czysto emocjonalne skłaniają się do podejmowania deontologicznych decyzji.

5) Krytyce można poddać także konsekwencjonalizm. Przy praktycznym przeprowadzeniu rachunku korzyści i konsekwencji pojawiają się trudności. Należałoby bowiem uwzględnić wszystkie osoby powiązane z danym działaniem. Jednak przy wielu działaniach trudno ustalić, kto dokładnie jest nim dotknięty i jak duży jest to krąg osób. Podjęcie decyzji dotyczących faktycznie jednej osoby lub małego kręgu osób może wyglądać na relatywnie proste, jednak rozważania mające wpływ na większe systemy (np. na system zdrowia) są o wiele bardziej złożone i prawie niemożliwe do przeprowadzenia, gdyż należałoby w nich uwzględnić dane, którymi nie możemy dysponować. Oprócz skutków jakiegoś działania pojawiają się dodatkowe czynniki, które niejako intuicyjnie wchodzą w zakres rozważań moralnych. Jeśli przykładowo obiecałem coś uczynić lub czyimś działaniem został dotknięty ktoś mi bardzo bliski, to pojawiają się dodatkowe moralne obowiązki i oceny sumienia, które umykają przy czystej obserwacji skutków działania.

6) Eksperymenty Greene’a konfrontują nas z jeszcze jednym pytaniem, które możemy odnieść do deontologicznego sumienia: jak to jest, że niektóre z badanych osób decydują raczej w sposób uczuciowy, inne raczej w sposób racjonalny, jeszcze inne raczej pragmatycznie, i inne bardziej pryncypialnie? Niektórzy nie zastanawiali się ani przez moment, czy strącić, czy nie strącić grubego człowieka z kładki. Czy zobowiązywała ich żelazna reguła: nigdy nie używaj drugiego człowieka jako środka do osiągnięcia celu? Być może inni mówili sobie, że uratowanie pięciu osób znaczy więcej aniżeli poświęcenie jednej. Jak powstają tego typu indywidualne struktury sumienia? Dlaczego tworzą się emocjonalne i racjonalne, instynktowne i nabyte kulturowo elementy sumienia? Jak łączą się one wzajemnie w jedno, tworząc jedność sumienia? Odpowiedzi na te pytania należy szukać 
w dalszych badaniach interdyscyplinarnych, uwzględniających chociażby badania psychologii rozwojowej.

7) Po uwzględnieniu powyższych punktów w nowym świetle ukazuje się etyka św. Tomasza z Akwinu, która niejako łączy teorie deontologiczne z teoriami konsekwencjonalistycznymi. Kładąc nacisk na wyniki działań (cechy działań), możemy powiedzieć, że etyka ta jest bardziej deontologiczna aniżeli konsekwencjonalistyczna. Chociaż obecna w niej teza, że działanie musi być skierowane na to, co jest dobre, zbliża ją ogólnie do konsekwencjonalizmu. Neuroobrazowanie tego typu modeli dylematów sumienia wymagałoby na chwilę obecną zbudowania precyzyjniejszych metodologii badań.

\section{Podsumowanie}

Kilka uwag podsumowujących na temat neurologicznych podstaw sumienia i na temat różnicy między deontologią a konsekwencjonalizmem:

1) Należy się generalnie zgodzić z Churchland, że teoria moralności (podobnie jak inne teorie naukowe) musi umieć wyjaśnić badane przez fakty i być otwarta na interdyscyplinarne badania empiryczne (z zakresu neurofilozofii, jak tego chce Churchland, czy też z zakresu kognitywistyki lub psychologii moralności). Ostatecznie jednak jakakolwiek teoria moralności zawierająca element normatywny odwołujący się do sądów (jako coś przeciwnego do zajmowania się jedynie zachowaniami) musi zawierać jakieś preskryptywne zdania, które nie są koniecznie empiryczne (do których mogą należeć sądy sumienia). Oznacza to konieczność poszukiwania metody rozstrzygającej pomiędzy systemami etycznymi zawierającymi coś więcej aniżeli zgodność z aktualnym poznaniem naukowym. Tego typu zgodność może być jednym z kryteriów wyboru teorii moralności, lecz nie jedynym.

2) Analizując uzyskane neurobiologiczne, a także psychologiczne wyniki, trudno, moim zdaniem, mówić o raz na zawsze ustalonym, niezmiennym sumieniu. Sumienie rozwija się, rozbudowuje (przy- 
najmniej do osiągnięcia przez osobę wieku dojrzałego). Cechuje je raczej forma dynamiczna niż statyczna. Konsekwencją tego jest to, że patrząc z dłuższej perspektywy, sądy własnego sumienia mogą ulegać zmianie, i dlatego należy dbać o ich formowanie. Poprzez swoje myślenie, odczuwanie, chcenie i działanie formujemy swój własny mózg, a tym samym odciskamy piętno na naszym sumieniu. Każda osoba jest współodpowiedzialna za to, jakie znaczenie posiada jej głos sumienia, gdy zdecyduje się na takie czy inne działanie. Aby sprostać wymaganiom własnej odpowiedzialności, potrzeba ciągłego ćwiczenia, ciągłego polerowania neuronalnego podłoża sumienia i przyzwoitości. Są to prawdy znane z etyki klasycznej i jej nauki o konieczności formowania sumienia. Analizowane wyżej badania empiryczne wskazały na przyrodnicze podstawy tych prawd, niemniej jednak nie uwzględniają one perspektyw długofalowych.

3) Osoby badane przez Greene’a i innych wykazywały większą tendencję do podejmowania decyzji deontologicznych, gdy znalazły się w sytuacji osobistego dokonania czynu niejednoznacznego moralnie. Jeśli jednak rozważały abstrakcyjne, niedotykające ich emocjonalnie dylematy, to wykazywały tendencję do myślenia konsekwencjonalistycznego. Pojawia się pytanie, na ile deontologia z jej nauką o sumieniu jest swoistą racjonalizacją. Czy rzeczywiście oceny deontologów kierują się przypisywanymi im racjami, czy też są sterowane emocjami (pożądaniem, poczuciem wstrętu, zamiarem skrzywdzenia kogoś, osobistym użyciem siły). Konsekwencjalizm skorelowany jest z charakterystycznie ludzkimi, poznawczymi, racjonalnymi strukturami naszego mózgu. Dzięki nim możemy myśleć abstrakcyjnie. Tym samym konsekwencjalizm wydaje się bardziej racjonalny aniżeli deontologia kierowana przez emocje. Z tego też względu Greene przyjmuje, że nasze normatywne analizy najadekwatniejszego zbioru akceptowalnych zachowań powinny kierować się normami konsekwencjalizmu. Wyżej starałem się pokazać, że teza ta nie jest jednoznaczna. 
4) Osoby z uszkodzeniami w obrębie brzuszno-przyśrodkowej kory przedczołowej (VMPFC) - która od strony neuronalnej jest jakoś odpowiedzialna za funkcje emotywne - preferują wybory konsekwencjonalistyczne i znacznie częściej w eksperymentach skłaniają się ku zabiciu niewinnego człowieka celem uratowania innych osób. Osoby te w mniejszym stopniu się wahają niż osoby z grupy kontrolnej (które postanowiły pchnąć człowieka na tory celem zatrzymania pędzącej drezyny). Badania za pomocą fMRI pokazały, że funkcjonowanie VMPFC ma udział w prospołecznym, ocenianym przez sumienie zachowaniu, łącznie z przyznaniem się do winy, zakłopotaniem i współczuciem. Aktywacja DLPFC przy prezentacji nieosobistych dylematów moralnych sugeruje beznamiętną ocenę kosztów i korzyści dokonywaną przy sądach moralnych.

5) Pomimo sensacyjnych ustaleń współczesnych neuronauk, z punktu widzenia filozoficznego sumienie można nadal traktować jako zjawisko pierwotne. To znaczy trudno je zdefiniować w języku neuronauk, czy też zbadać - w najlepszym razie można je „przepytać” co do jego „faktycznego” doznawania i znaczenia. Pośród nauk humanistycznych i społecznych panuje przekonanie, że sumieniu przypada fundamentalne znaczenie dla moralności osoby. Z doświadczenia potocznego wiemy, że deficyty sumienia jako całości prowadzą niechybnie do perwersji osobowości.

6) Niejasne pozostaje, co się dokładnie dzieje, gdy np. instynktowne czy intuicyjne wyrzuty sumienia osoby wchodzą w konflikt z jej racjonalnymi decyzjami. Lub gdy subiektywne decyzje sumienia są przez osobą tak poważnie brane pod uwagę, że nie jest ona w stanie żyć z innymi ludźmi. Albo też gdy sumienie społeczne jest bardzo słabe, gdyż ludzie za bardzo myślą o sobie. Przedstawione wyżej wyniki badań opisują to częściowo, lecz należałoby wyjaśnić, jakie znaczenie mają nieświadome elementy sumienia i jak dalece zmiany sumienia urzeczywistniają się nieświadomie lub świadomie. Aby odpowiedzieć na tego typu pytania, wskazane jest prowadzenie interdyscyplinarnych badań kognitywistycznych. Na przykład 
za pomocą fMRI można by próbować ustalić, jakie zmiany zachodzą przy dojrzewaniu sumienia u dzieci między czwartym a dwunastym rokiem życia. Oczywiście wcześniej należy się upewnić, czy pole magnetyczne w fMRI nie wpływa negatywnie na mózg czteroletniego dziecka. Badania takie można by przeprowadzić na dzieciach wyrastający w różnych, odmiennych kulturach, z których jedne są naznaczone religijnym, wspólnotowym sumieniem, a inne nie. Za pomocą neuroobrazowania można badać ludzi z kręgów kulturowych w czasie, kiedy myślą nad decyzjami sumienia. Dałoby to początek nie tylko interdyscyplinarnym, lecz także interkulturowym badaniom nad sumieniem.

\section{Bibliografia}

Biesaga, T. 2004. „Konsekwencjonalizm.” W Powszechna encyklopedia filozoficzna. Lublin: KUL, Polskie Towarzystwo Tomasza z Akwinu, t. 5: 801-803.

Blackburna, S. 1993. How To Be an Ethical Anti-Realist. Essays in Quasi-Realism. New York: Oxford University Press.

Bremer, J. 2013. „Czym jest neuromarketing?” Communication Today 1/4: 18-34.

-. 2013. Czy wolna wola jest wolna? Kompatybilizm na tle badań interdyscyplinarnych.

Kraków: WAM.

-. 2005. Jak to jest być świadomym. Analityczne teorie umysłu a problem świadomości.

Warszawa: IFiS PAN.

-. 2010. Wprowadzenie do filozofii umysłu. Kraków: WAM.

Brians, P. 2013. Common Errors in English Usage, Portland/OR: William, James \& Company.

Churchland, P. 2013. Moralność mózgu. Co neuronauka mówi o moralności. Kraków: Copernicus Center Press. Przekład: M. Hohol. [oryg.: 2011. Braintrust: What Neuroscience Tells Us about Morality. Princeton: Princeton UP.].

Damasio, A.R. 2011. Błąd Kartezjusza. Emocje, rozum i ludzki mózg. Poznań: Rebis. Przekład: M. Karpiński.

Dennetta, D. 1993. La conscience expliquée. Paris: Odile Jacob.

Dewey, J. 1906. ”The Terms 'Conscious' and 'Consciousness'.” Journal of Philosophy, Psychology and Scientific Method 3: 39-41. DOI: http://dx.doi. org/10.2307/2011714. 
Duch, W. 2008/2009. „Emocje i układ limbiczny.” http://www.fizyka.umk.pl/ duch/ Wyklady/Mozg/07-3-limbiczny.htm, dostęp: 26.07.14.

Duus, P. 1989. Diagnostyka topograficzna w neurologii. Warszawa: Państwowy Zakład Wydawnictw Lekarskich.

Greene, J. 2007. “The Secret Joke of Kant's Soul.” W W. Sinnott-Armstrong (red.), Moral Psychology, t. 3: The Neuroscience of Morality: Emotion, Brain Disorders, and Development, Cambridge/MA, and London: MIT Press, 35-79.

Hallgarth, M.W. 1996. „Consequentialism and Deontology.” W R. Chadwicks (red.), Encyclopedia of Applied Ethics. San Diego: Academic Press, t. 1: 609-621.

Hanson, J.L., Chung, M.K., Avants, B.B., Shirtcliff, E.A., Gee, J.C., Davidson, R.J., Pollak, S.D. 2010. “Early Stress Is Associated with Alterations in the Orbitofrontal Cortex: A Tensor-Based Morphometry Investigation of Brain Structure and Behavioral Risk.” The Journal of Neuroscience 22/30.

Hoffman, M.B. 2014. The Punisher's Brain. N. York: Cambridge University Press.

Hume, D. 1963. Traktat o naturze ludzkiej. Warszawa: PWN. Przekład: Cz. Znamierowski.

Kant, I. 1984. Krytyka praktycznego rozumu. Warszawa: PWN. Przekład: J. Gałecki.

-. 2005. Metafizyka moralności. Warszawa: WN PWN. Przekład: E. Nowak.

Koenigs, M., Young, L., Adolphs, R., Tranel, D., Cushman, F., Hauser, M., Damasio, A. 2007. "Damage to the Prefrontal Cortex Increases Utilitarian Moral Judgments." Nature 446: 908-911.

Kranich-Strötz, Ch. 2008. Selbstbewusstsein und Gewissen: Zur Rekonstruktion der Individualitätskonzeption bei Peter Abaelard - Subjekt, Zeit, Geschichte. Berlin: LIT-Verlag, t. 2.

Kringelbach, M.L., Rolls, E.T. 2004. “The Functional Neuroanatomy of the Human Orbitofrontal Cortex: Evidence from Neuroimaging and Neuropsychology.” Progress in Neurobiology 72: 341-372.

Neubertemail, F.-X., Mars, R.B., Thomas, A.G., Sallet, J., Rushworth, M.F.S. 2014. "Comparison of Human Ventral Frontal Cortex Areas for Cognitive Control and Language with Areas in Monkey Frontal Cortex.” Neuron 3/81: 700-713.

Nunner-Winkler, G. 2006. "Freiwillige Selbstbindung aus Einsicht - ein moderner Modus moralischer Motivation.” W H.F. Klemme, M. Kühn, D. Schönecker (red.), Moralische Motivation: Kant und die Alternativen. Hamburg: Felix Meiner, 165-192.

Raab, G., Gernsheimer, O., Schindler, M. 2009. Neuromarketing: Grundlagen - Erkenntnisse - Anwendungen. Wiesbaden: Gabler Verlager. 
Singer, T., Seymour, B., O’Doherty, J., Kaube, H., Dolan, R.J., Frith, Ch.D. 2004. "Empathy for Pain Involves the Affective but not Sensory Components of Pain." Science 303: 1157-1162. DOI: http://dx.doi.org/10.1126/science.1093535.

Stach, R., Popek, A.M. 2013. „Decyzje ekonomiczne i społeczne z perspektywy pogranicza neuronauk oraz nauk o zarządzaniu.” International Journal of Contemporary Management 2/13: 48-57.

Tomasz z Akwinu. 1952. Summa Theologiae. Romae: Marietti.

Urbańczyk, S. (red.). 1977-1981. Słownik staropolski. Wrocław: Ossolineum, t. 8: 505-506.

Wayne, M. 2006. Conscience and Consciousness: Rousseau's Critique of the Stoic Theory of Oikeosis. philosophy.fas.nyu.edu/object/philo.courses.ml06.html, dostęp: 24.05.14. 